\title{
Strategi Pemerintah Daerah dalam Tinjauan Program Kota Tanpa Kumuh (Studi pada Kelurahan Gading Kasri, Kecamatan Klojen, Kota Malang)
}

\author{
Mochamad Chazienul Ulum ${ }^{\text {a* }}$, Dini Heksa Anggraini ${ }^{\text {a }}$ \\ ${ }^{a}$ Universitas Brawijaya, Malang, Jawa Timur, Indonesia
}

INFORMASI ARTIKEL

Article history:

Dikirim tanggal: 04 Maret 2021

Revisi pertama tanggal: 15 Maret 2021

Diterima tanggal: 26 Maret 2021

Tersedia online tanggal: 14 April 2021

Keywords: government strategy, of slum settlements, the City Without Slums (KOTAKU) program

\section{ABSTRACT}

The problem of slum settlements is a big challenge for both central and local governments. To overcome this problem, the Directorate General of Human Settlements conducted national development through the City Without Slums (KOTAKU) program. KOTAKU is a program to manage slum settlements into habitable settlements through community-based infrastructure development. Kelurahan Gading Kasri of Malang City is one of the sub-districts chosen by the Malang City Government to implement the City Without Slums program. Strategies in handling the slum areas in Gading Kasri Village can be analyzed with the theory of types of strategies by Korten, which include organizational strategies, program strategies, resource support strategies, and institutional strategies.

\section{INTISARI}

Masalah permukiman kumuh merupakan tantangan besar bagi pemerintah pusat maupun pemerintah daerah. Untuk mengatasi permasalahan tersebut, Direktorat Jenderal Cipta Karya menyelenggarakan pembangunan nasional melalui program Kota Tanpa Kumuh (KOTAKU). KOTAKU merupakan program penanganan permukiman kumuh menjadi permukiman yang layak huni melalui pembangunan infrastruktur yang berbasis masyarakat. Kelurahan Gading Kasri Kota Malang merupakan salah satu kelurahan yang dipilih Pemerintah Kota Malang untuk melaksanakan program Kota Tanpa Kumuh. Strategi dalam penanganan kawasan Kumuh di Kelurahan Gading Kasri ini dapat dianalisis dengan teori tipe-tipe strategi dari Korten, yang meliputi strategi organisasi, strategi program, strategi pendukung sumber daya, dan strategi kelembagaan.

2021 FIA UB. All rights reserved.

\section{Pendahuluan}

Indonesia mengalami masalah pertumbuhan penduduk yang selalu meningkat setiap tahunnya. Tingginya jumlah penduduk akan mempengaruhi kondisi suatu perkotaan, baik pada kondisi internal maupun eksternal. Misalnya, pertumbuhan penduduk yang tidak seimbang dengan luasnya kawasan permukiman yang tersedia, sehingga hal ini akan menimbulkan suatu masalah.

Munculnya permukiman kumuh disebabkan oleh berbagai faktor, salah satunya adalah keberadaan kelompok urban yang ingin memperjuangkan kehidupan mereka di wilayah perkotaan untuk mencari pendidikan maupun pekerjaan yang layak. Proses urbanisasi akan menambah volume penduduk di suatu kota, sehingga menyebabkan berkurangnya lahan permukiman yang

\footnotetext{
* Corresponding author. Tel.: +62-853-3491-6305; e-mail: mochamad.ulum@gmail.com
} 
tersedia. Beberapa dari kelompok urban tidak mampu memenuhi standar hidup yang layak, mereka membangun tempat tinggal semampu mereka dan tidak memperhatikan standar permukiman yang telah ditetapkan oleh pemerintah, sehingga berpotensi memunculkan area permukiman kumuh. Permasalahan ini akan berdampak pada pelaksanaan penataan ruang serta kebijakan pembangunan permukiman dan perumahan.

Terbatasnya lahan yang tersedia diwilayah perkotaan memungkinkan masyarakat untuk memanfaatkan lahan-lahan, seperti bantaran sungai, tepi rel kereta api, dan tempat-tempat lainnya yang tidak seharusnya digunakan untuk membangun tempat hunian. Akhirnya, kondisi ini akan mengakibatkan munculnya permukiman kumuh dan diikuti dengan lahirnya permasalahan sosial lainnya.

Berdasarkan Undang-Undang Nomor 1 Tahun 2011 Pasal 1 tentang Perumahan dan Kawasan Permukiman mendefinisikan tentang permukiman kumuh, yaitu "Permukiman kumuh adalah permukiman yang tidak layak dikarenakan ketidakteraturan bangunan, tingkat kepadatan bangunan yang tinggi, dan kualitas bangunan serta sarana dan prasarana yang tidak layak atau memenuhi syarat".

Pemerintah terus berupaya mengatasi masalah permukiman kumuh di Indonesia. Direktorat Jenderal Cipta Karya Menginisiasi pembangunan melalui Program Kota Tanpa Kumuh (KOTAKU). Program Kotaku dirancang untuk mendukung daerah-daerah dalam penanganan permukiman kumuh dan menyiapkan masyarakat sebagai subjek dari pembangunan melalui revitalisasi peran BKM (Badan Keswadayaan Masyarakat). Berdasarkan Pedoman Teknis Program KOTAKU Tahun 2015, Program KOTAKU dilaksanakan di 34 provinsi yang tersebar di 269 kabupaten/ kota.

Kelurahan Gading Kasri, Kecamatan Klojen Kota Malang merupakan salah satu kelurahan yang menjadi kawasan prioritas penanganan kumuh. Kelurahan Gading Kasri mengalami masalah kekumuhan diberbagai aspek, seperti drainase, sanitasi, jalan lingkungan, dan tata bangunan. Berdasarkan pemaparan tersebut, maka tujuan penelitian ini adalah untuk menganalisis strategi Pemerintah Kota Malang dalam menangani masalah lingkungan melalui Program KOTAKU, termasuk di Kelurahan Gading Kasri.

\section{Teori}

\subsection{Konsep Pembangunan}

Pembangunan merupakan bentuk perubahan sosial yang terarah dan terencana melalui berbagai macam kebijakan yang bertujuan untuk meningkatkan taraf kehidupan masyarakat. Pembangunan diartikan sebagai suatu proses multidimensional yang meliputi perubahan dalam struktur sosial, perubahan dalam sikap hidup masyarakat dan perubahan dalam kelembagaan nasional, selain itu, pembangunan juga meliputi perubahan dalam tingkat pertumbuhan ekonomi, pengurangan ketimpangan pendapatan nasional dan pemberantasan kemiskinan (Todaro, 2000, h. 17).

Nilai-nilai adalah inti dari perselisihan tentang definisi pembangunan. Hal ini dapat menyangkut tentang apa yang harus diperbaiki, bagaimana cara memperbaikinya dan, terutama, pertanyaan tentang siapa yang memutuskan? Namun, sejak Tahun 1990-an, pembangunan telah didefinisikan dengan cakrawala yang lebih pendek terkait dengan tujuan kebijakan dan indikator kinerja (seperti pertumbuhan pendapatan per kapita dan pengurangan kemiskinan).

\subsection{Strategi}

Pencapaian tujuan dalam suatu organisasi perlu menetapkan suatu strategi sebagai langkah awal dalam memulai kegiatan, dimana setiap organisasi menggunakan tipe strategi yang berbeda-beda. Menurut Korten (dalam Salusu, 2003, h. 104-105), strategi dikelompokkan menjadi beberapa tipe, yaitu sebagai berikut:

a) Strategi Organisasi

Strategi ini berkaitan dengan perumusan, misi, tujuan, nilai-nilai dan inisiatif strategi yang baru. Pembatasan-pembatasan diperlukan, yaitu apa yang perlu dilakukan dan untuk siapa.

b) Strategi Program

Strategi ini lebih memperhatikan pada implikasiimplikasi strategi dari suatu program tertentu. Apa kira-kira dampaknya apabila suatu program tertentu dilancarkan atau diperkenalkan, apa dampaknya bagi sasaran organisasi.

c) Strategi Pendukung Sumber Daya

Strategi sumber daya ini memusatkan perhatian pada memaksimalkan pemanfaatan sumber-sumber daya esensial yang tersedia guna meningkatkan kualitas kinerja organisasi. Sumber daya tersebut dapat berupa tenaga, keuangan, teknologi, dan sebagainya.

d) Strategi Kelembagaan

Fokus dari strategi institusional adalah mengembangkan kemampuan organisasi untuk melaksanakan inisiatif-inisiatif strategi.

\subsection{Konsep Program}

Program dapat dikatakan sebagai bentuk perencanaan yang berfungsi untuk menyelesaikan masalah yang muncul akibat ketidaksesuaian teori dengan praktik. Terry (dalam Tachjan, 2006, h. 32) mengemukakan bahwa "A program can be defined as a comprehensive plan that includes future use of different resources in an integrated pattern and established 
a sequence of required actions and times schedules for each in order to achieved stated objectives, policies, procedures, methods, standards, and budgets" (suatu program dapat didefinisikan sebagai rencana komprehensif yang mencakup penggunaan sumber daya yang berbeda di masa depan dalam pola terintegrasi dan menetapkan urutan tindakan dan jadwal waktu untuk mencapai tujuan, kebijakan, prosedur, metode, standar, dan anggaran yang ditetapkan).

\subsection{Permukiman Kumuh}

\subsubsection{Permukiman Berkelanjutan}

Pemerintah Indonesia merumuskan agenda baru di perkotaan indonesia sebagai respon dari New Urban Agenda yang salah satu poin pentingnya adalah permukiman atau perumahan berkelanjutan. Berikut merupakan skema dari konsep pembangunan berkelanjutan:

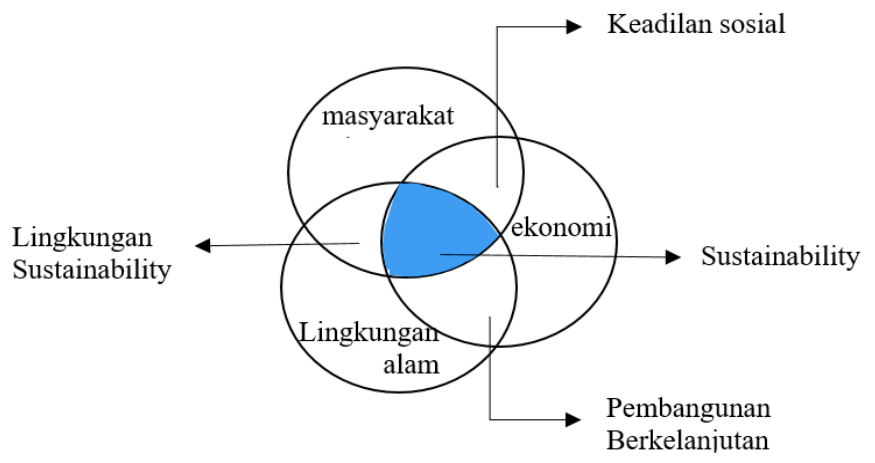

Gambar 1 Konsep Pembangunan Berkelanjutan Sumber: Sabaruddin, 2016, h. 82

\subsubsection{Pembangunan Kawasan Permukiman Kumuh}

Kawasan kumuh sering dilihat sebagai kawasan yang identik dengan permukiman yang padat, jalan sempit, serta jumlah penduduk yang tinggi. Berdasarkan Undang-Undang No.1 pasal 1 Tahun 2011 tentang perumahan dan kawasan permukiman, permukiman kumuh adalah permukiman yang tidak layak huni karena ketidakteraturan bangunan, tingkat kepadatan bangunan yang tinggi, dan kualitas bangunan serta sarana dan prasarana yang tidak memenuhi syarat.

\section{Metode Penelitian}

Metedologi penelitian yang digunakan pada penelitian ini adalah metode penelitian deskriptif dengan pendekatan kualitatif. Dalam penelitian ini data diperoleh melalui wawancara, obeservasi, dan penelusuran dokumen. Sedangkan analisis yang digunakan dalam penelitian ini adalah analisis data Creswell (2010) yang penulis anggap mampu menerjemahkan semua data yang ada menjadi suatu informasi.

\section{Hasil Penelitian dan Pembahasan}

Kelurahan Gading Kasri menjadi bagian dari Kecamatan Klojen Kota Malang, dimana luas wilayahnya mencapai 90,98 hektar, dengan koordinat wilayah terletak pada Longitude: -7.9790693 dan Latitude: 112. 6219486 dan secara administratif, di Kelurahan Gading Kasri terdapat 6 RW dan 50 RT.

Gading Kasri merupakan salah satu kelurahan yang ditetapkan sebagai wilayah yang kumuh dan perlu ditangani melalui program Kota Tanpa Kumuh. Berdasarkan amanat Surat Edaran Direktur Jenderal Cipta Karya nomor: 40/SE/DC/2016 tentang Pedoman Umum Program Kota Tanpa Kumuh, Kota Malang telah membentuk kelompok kerja Perumahan dan Permukiman (Pokja PKP), yakni terdiri dari Dinas Perumahan dan Kawasan Permukiman (atau yang sekarang digabung dengan DPU menjadi DPUPKP), kemudian juga terdapat pendamping atau fasilitator program KOTAKU di kota Malang diantaranya adalah Koordinator Kota Fasilitator P2KPP (Korkot), Asisten Kota Pemberdayaan Masyarakat (Askot), Senior Fasilitator (SF) dan Fasilitator Kelurahan (Faskel) yang memiliki tugas dan fungsi yang berbeda-beda.

Adapun beberapa tujuan dari Program Kota Tanpa Kumuh, antara lain dijabarkan sebagai berikut:

a) Menurunnya luas permukiman kumuh;

b) Tersusunnya rencana penanganan permukiman kumuh tingkat kabupaten/ kota dan tingkat masyarakat yang terintegrasi dalam Rencana Pembangunan Jangka Menengah Daerah (RPJMD); dan

c) Terlaksananya aturan bersama sebagai upaya perubahan perilaku hidup bersih dan sehat masyarakat dan pencegahan kumuh.

Permasalahan kumuh di Kelurahan Gading Kasri meliputi berbagai aspek, seperti drainase, sanitasi, persampahan, tata bangunan dan lain sebagainya. Kawasan kumuh yang terdapat di Kelurahan Gading Kasri tersebar di empat RW, yaitu RW 1, RW2, RW 3 dan RW6.

Penentuan kawasan kumuh pada program KOTAKU didasakan pada pengamatan yang dilakukan di lapangan oleh Koordinator Kota (Korkot). Selain itu, penentuan kawasan kumuh juga didasarkan pada keluhan dari masyarakat terkait dengan masalah kekumuhan yang dialami di wilayahnya. Lokasi-lokasi yang telah ditetapkan tersebut nantinya akan disebut dengan kawasan prioritas.

Penentuan kawasan Prioritas di Kelurahan Gading Kasri melalui proses yang panjang dengan musyawarah yang matang. Berangkat dari keluhan masyarakat yang disampaikan saat rapat RT kemudian disampaikan kepada BKM. Selanjutnya BKM bersama dengan 
fasilitator kelurahan mendiskusikan dan mempertimbangkan wilayah-wilayah yang nantinya akan dijadikan kawasan prioritas. Lokasi ini tidak lepas dari indikator yang telah ditentukan dalam pedoman Program Kota tanpa Kumuh. Berikut merupakan grafik kondisi permasalahan diwilayah prioritas Kelurahan Gading Kasri:

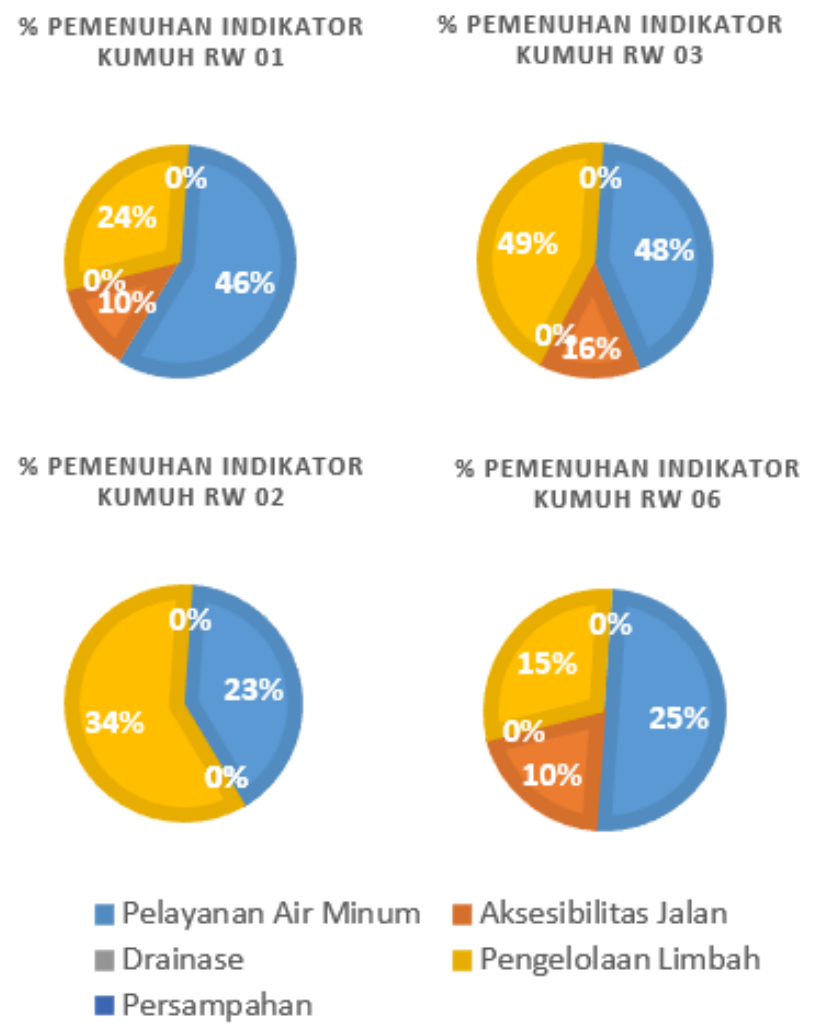

Gambar 2 Grafik Persentase Permasalahan

Kekumuhan di Kelurahan Gading Kasri

Sumber: Dokumen RPLP Kelurahan Gading Kasri

(hal IV-12), Tahun 2016 -2021

Berdasarkan grafik diatas menunjukkan bahwa permasalahan kekumuhan di Kelurahan Gading Kasri paling banyak terkait dengan pelayanan air minum, sanitasi atau pengelolahan limbah dan aksesibilitas jalan. Berdasarkan dokumen RPLP Kelurahan Gading Kasri sebanyak $24 \%$ penduduk belum terlayani PDAM, $43 \%$ penduduk memiliki pembuangan limbah rumah tangga yang bercampur dengan drainase, serta $42 \%$ permukiman warga belum terlayani akses jalan yang minimum memadai atau dengan kata lain memiliki lebar jalan $<1,5 \mathrm{M}$.

Menurut Korten (dalam Salusu, 2003, h. 104-105), strategi dikelompokkan menjadi beberapa tipe, yaitu strategi organisasi (corporate strategy), strategi program (program strategy), strategi pendukung sumber daya (resource support strategy), dan strategi kelembagaan (institutional strategy). Setiap tipe strategi tersebut masing-masing memiliki kelebihan dan kekurangan, sehingga semua tipe strategi saling melengkapi satu sama lain.
Pembahasan mengenai analisis strategi Pemerintah Kota Malang dalam mengatasi masalah permukiman melalui Program KOTAKU di Kelurahan Gading Kasri menurut teori strategi dari Korten:

\subsection{Strategi Organisasi}

Pada tingkat kelurahan masyarakat bekerjasama dengan pemerintah kelurahan bersama dengan kelompok atau organisasi yang ada pada kelurahan melalui keterpaduan program. Jika dilihat dari strategi organisasi, maka organisasi dimasyarakat yang berkaitan secara langsung dengan program Kota Tanpa Kumuh adalah Badan Keswadayaan Masyarakat (BKM). Dalam program ini BKM berperan sebagai penghubung antara pemerintah dengan masyarakat serta melakukan pendataan titik-titik kumuh di wilayahnya.

Badan Keswadayaan Masyarakat bekerja sama dengan lembaga yang ada diwilayah kelurahan lainnya seperti Kelompok Swadaya Masyarakat, Lembaga Pemberdayaan Masyarakat (LPMK) Pembinaan Kesejahteraan Keluarga (PKK) Rukun Warga (RW), Rukun Tetangga (RT) yang sangat berperan dalam membantu proses perwujudan program Kota Tanpa Kumuh. Pelaksanaan program kota tanpa kumuh ditingkat kelurahan didampingi oleh faskel atau fasilitator kelurahan yang berkoordinasi dengan badan keswadayaan masyarakat (BKM).

Strategi yang dilakukan oleh BKM dikelurahan adalah dengan melakukan bimbingan kepada masyarakat dan mengikuti pelatihan yang diadakan oleh pemerintah. Pemberian bimbingan dapat berupa informasi terkait program yang dilaksanakan disertai dengan rincian tugas dari setiap stakeholder yang terlibat. Selain itu pemberian bimbingan juga dapat berupa sosialisasi terkait Program Kota Tanpa Kumuh mulai dari perencanaan hingga pelaksanaannya. Pemberian bimbingan biasanya berasal dari instansi pemerintah atau Organisasi Perangkat Daerah (OPD) yang terkait.

Pemberian bimbingan berupa latihan kepada masyarakat terdiri dari dua bagian yaitu aspek teknis dan non teknis. Pelatihan ini diberikan secara berkala kepada masyarakat, jadi masyarakat terus didampingi oleh fasilitator masing-masing yang telah ditentukan sehingga masyarakat dapat mengaplikasikan program dengan benar dan dapat mencapai output yang diharapkan.

Strategi lainnya yang dilakukan oleh BKM disetiap kelurahan adalah dengan mendata setiap RT dan RW dalam memberikan keluhan-keluhan yang dialami diwilayahnya. Kegiatan dalam penanganan kumuh berbeda disetiap wilayah sesuai kebutuhannya. Selanjutnya, dari semua keluhan yang didapat disusun dalam bentuk dokumen yang disebut dengan Rencana Penataan Lingkungan Permukiman (RPLP). 


\subsection{Strategi Program}

Strategi pendampingan dalam program KOTAKU meliputi kolaborasi antara pemerintah, masyarakat, dan OPD terkait dalam penyusunan rencana peraturan daerah (Raperda) tentang pencegahan dan peningkatan kualitas permukiman kumuh, pendampingan penyusunan rencana pencegahan, dan peningkatan kualitas permukiman kumuh, keterpaduan penanganan permukiman kumuh, penanganan kumuh berbasis masyarakat dengan revitalisasi BKM dari penanggulangan kemiskinan ke penanganan kumuh.

Berdasarkan Pedoman Umum Program KOTAKU strategi Operasional dalam penyelenggaraan program adalah:

a) Setiap kota yang terpilih untuk melaksanakan program KOTAKU terdapat Tim Kotaku yang berperan sebagai pendamping-pendamping dari setiap kelurahan yang melaksanakan program Kota Tanpa Kumuh guna mendapatkan bimbingan dan Pelatihan. Bimbingan dan pelatihan ini diberikan kepada Camat, Lurah, BKM, KSM serta masyarakat lainnya. Bimbingan dan pelatihan yang diberikan oleh tim pendamping dilakukan secara bertahap dengan berbagai tema, sesuai dengan kebutuhan masyarakat; dan

b) Bimbingan dan pelatihan yang diberikan kepada masyarakat terdiri dari dua aspek, yaitu aspek teknis dan non teknis. Aspek teknis merupaan pelatihan yang bersifat praktek dimana peserta pelatihan akan melaksanakan kegiatan OJT/ praktik lapang dilokasi kegiatan. Sedangkan pelatihan non teknis yang diberikan oleh pendamping berupa cara penyusunan perencanaan RPLP dan meningkatkan kualitas RPLP, dan lain sebagainya.

\subsection{Strategi Pendukng Sumber Daya}

Pendukung sumber daya dalam program KOTAKU adalah masyarakat itu sendiri. Dimana setelah melakukan penentuan kawasan prioritas dan keputusan bersama telah diperoleh maka masyarakat setempat akan diminta untuk membentuk Kelompok Swadaya Masyarakat (KSM). Pembentukan KSM ini dilaukan dengan cara musyawarah antar seluruh masyarakat.

Dalam pelaksanaan program Kota Tanpa Kumuh KSM dapat dikatakan sebagai panitia pelaksana program, karena merupakan bentukan dari masyarakat itu sendiri sehingga diharapkan bimbingan dan pelatihan yang diberikan oleh pemerintah kepada KSM dapat diaplikasikan secara optimal serta mampu menjawab permasalahan yang ada di RW itu sendiri.

Dalam pogram KOTAKU, KSM memiliki peran yang sangat penting, salah satunya adalah mengawasi pelaksanaan program yang telah direncanakan serta bertanggung jawab dalam memelihara hasil dari program yang telah diberikan tersebut, terutama apabila program yang direalisasikan tersebut bersifat fisik seperti pembangunan fasilitas umum dan jaringan prasarana. Oleh sebab itu, tingkat partisipasi masyarakat sangat menentukan keberhasilan program Kota Tanpa Kumuh karena dalam program yang menuntut agar masyarakat dapat mandiri dan berkelanjutan.

\subsection{Strategi Kelembagaan}

Berdasarkan amanat Surat Edaran Direktur Jendral Cipta Karya Nomor: 40/SE/DC/2016 tentang pedoman umum program Kota Tanpa Kumuh, Kota Malang telah membentuk Kelompok Kerja Perumahan dan Permukiman (Pokja PKP). Pokja PKP terdiri dari berbagai pemerintah kota seperti OPD terkait, Bappeda, masyarakat, dan kelompok peduli lainnya. Adapun dinas yang secara spesifik menangani kawasan permukiman kumuh di Kota Malang adalah Dinas Perumahan dan Kawasan Permukiman (DISPERKIM), Bidang Perumahan dan Pertanahan.

Bidang Perumahan dan Pertanahan merupakan salah satu OPD yang tergabung dalam Pokja PKP Kota Malang. Tidak ada struktur organisasi yang dibentuk secara khusus untuk program KOTAKU melainkan hanya tim-tim pelaksana yang tergabung dalam Pokja PKP. Dalam mengatasi permasalahan kumuh di Kota Malang DISPERKIM berpedoman pada UU No. 1 Tahun 2011 tentang Perumahan dan Kawasan Permukiman.

Perumusan konsep dan strategi penanganan dilakukan berdasarkan hasil analisis permasalahan. Penanganan kumuh dilakukan melalui dua konsep penanganan, yang digambarkan pada skema berikut:

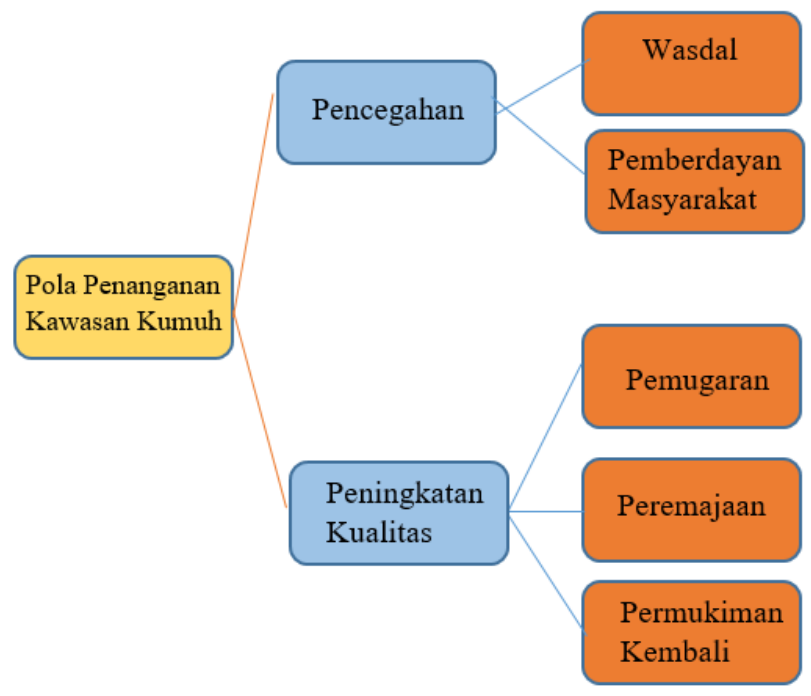

Gambar 3 Skema Penanganan Kawasan Kumuh

Sumber: UU. No.1 Tahun 2011 tentang Perumahan dan kawasan Permukiman

Terdapat perbedaan mendasar antara konsep pencegahan dan konsep peningkatan kualitas, yaitu terletak pada lokasi penanganannya. Pada konsep dan strategi pencegahan memiliki lingkup wilayah yang lebih luas, yakni pada lokasi-lokasi tertentu yang berdasarkan 
hasil analisa telah menunjukkan adanya potensi kumuh. Indikasi kumuh ini apabila tidak dicegah maka lama kelamaan akan menjadi wilayah kumuh baru. Sedangkan pada konsep dan strategi peningkatan kualitas memiliki cakupan wilayah yang lebih spesifik. Wilayah yang menjadi lingkup penerapan konsep dan strategi peningkatan kualitas kumuh adalah lokasi yang memiliki tingkat kekumuhan paling tinggi sehingga memerlukan penanganan dan harus diprioritaskan.

Tim dari DPUPKP juga melakukan monitoring secara berkala setiap bulannya, monitoring ini dilakukan sebagai bentuk pengawasan dari DPUPKP dan juga untuk mengetahui bagaimana kemajuan yang ada di masyarakat untuk memastikan bahwa tidak terjadi kendala dilapangan. Dalam jangka waktu tertentu, DPUPKP juga melakukan evaluasi secara rutin untuk melihat perkembangan dari kegiatan yang telah dilakukan, serta menganalisis kendala yang dialami selama pelaksanaan kegiatan. Dalam menangani kawasan kumuh di Kelurahan Gading Kasri, semua aspek tersebut memiliki peranan yang sangat penting san saling melengkapi. Adanya kerjasama yang baik dari masingmasing pihak sangat dibutuhkan.

\section{Kesimpulan}

Kelurahan Gading Kasri, Kecamatan Klojen, Kota Malang merupakan salah satu Kelurahan yang ditunjuk oleh pemerintah Kota Malang untuk melaksanakan program KOTAKU di wilayahnya. Wilayah kumuh di Kelurahan Gading Kasri tersebar di 4 RW, yaitu RW 01, RW 02, RW 03, dan RW 6. Menurut teori strategi dari Korten terdapat empat tipe strategi, yakni strategi organisasi, strategi program, strategi pendukung sumber daya dan strategi kelembagaan. Dalam hal ini BKM merupakan perwujudan dari strategi organisasi, masyarakat sebagai strategi pendukung sumber daya, program KOTAKU itu sendiri merupakan strategi program, dan DISPERKIM atau DPUPKP sebagai strategi kelembagaan. Masing-masing aspek memiliki peran dan tanggung jawabnya masing-masing yang saling melengkapi satu sama lain.

Di Kelurahan Gading Kasri semua aspek sudah menjalankan fungsinya dengan baik. Hal ini dibuktikan dengan adanya partisipasi dan inisiatif dari masyarakat Kelurahan Gading Kasri dalam keikutsertaan untuk mengikuti rapat dan juga pelaksanaan program. Fasilitator Kelurahan dan pendamping lainnya juga aktif dalam membimbing masyarakat untuk lebih mengetahui cara membuat RPLP dan kegiatan administratif lainnya. Kemudian DISPERKIM juga telah melakukan monitoring serta evaluasi secara berkala untuk melihat kemajuan dan juga kendala yang dialami selama pelaksanaan program.

\section{Daftar Pustaka}

Creswell, J.W. (2010). Research Design: Pendekatan Kualitatif, Kuantitatif dan Mixed. Yogyakarta: Pustaka Pelajar.

Kantor Kelurahan Gading Kasri. (2021). Dokumen RPLP Kelurahan Gading Kasri. Malang: Kantor Kelurahan Gading Kasri.

Sabaruddin, Arief. (2016). Permukiman Berkelanjutan: Telaah Psikologi Sosial. Jakarta: Erlangga.

Salusu, J. (2003). Pengambilan Keputusan Strategik untuk Organisasi Public dan Organisasi Non Profit. Jakarta: Grasindo.

Tachjan. (2006). Implementasi Kebijakan Publik. Bandung: AIPI Bandung.

Todaro, M.P. (2000). Pembangunan Ekonomi di Dunia Ketiga. Jakarta: Erlangga.

Undang-Undang Republik Indonesia Nomor 1 Tahun 2011 tentang Perumahan dan Kawasan Permukiman. 